\title{
Effect of Preparation and Storage Conditions on Physical and Chemical Properties of Puree, Puree Juices and Cloudy Juices Obtained from Pumpkin with Added Japanese Quince and Strawberries
}

\author{
Agnieszka NAWIRSKA-OLSZAŃSKA ${ }^{1}$, Anita BIESIADA ${ }^{2 *}$, \\ Anna SOKÓŁ-ŁĘTOWSKA ${ }^{1}$, Alicja Z. KUCHARSKA ${ }^{1}$ \\ ${ }^{1}$ University of Environmental and Life Sciencesin Wroctaw, Department of Fruit, Vegetable and Cereals Technology, Chetmońskiego St. 37/41, 50-375 Wroctaw, \\ Poland;agnieszkanawirska@up.urocpliannasokol-letowska@up.urocplialigjakucharska@up.uroc.pl \\ ${ }^{2}$ University of Environmental and Life Sciencesin Wroctaw, Department of Horticulture, Grunwaldzki Square 45, 50-375 Wroctaw, \\ Poland;anitabiesiada@up.uroc.pl(*orrespondingauthor)
}

\begin{abstract}
When evaluated in terms of taste, smell or active ingredients, pumpkin in itself is not very attractive as a raw material. Hence it seems recommendable to blend pumpkin with other fruits. The pumpkin chosen for the experiments was of the variety 'Karowita'. The aim of the study was to compare the physical and chemical properties of pumpkin samples based on different storage conditions. Pumpkin puree, puree juice and cloudy juices containing Japanese quince and strawberries were evaluated for their physical and chemical properties initially and after three months storage at temperatures of $4{ }^{\circ} \mathrm{C}$ and $30{ }^{\circ} \mathrm{C}$. Cloudy juices were prepared with pectolytic preparation. The extract dry matter in all the samples was at a similar level. Puree and puree juice had considerably higher viscosity than cloudy juices. The highest quantities of bioactive compounds were detected in slightly processed samples (puree, puree juice and cloudy juices) stored at $4{ }^{\circ} \mathrm{C}$. Increased content of polyphenols was observed in puree and puree juice after storage. However, in the remaining samples, there was observed a decrease in the content of the compounds. A considerable decrease in carotenoids took place in samples subjected to pressing, where the amount of assayed carotenoids in puree was $5.24 \mathrm{mg} / 100 \mathrm{~g}$ fresh matter (FM), $4.15 \mathrm{mg} / 100 \mathrm{~g}$ FM in puree juice, and 0.18-0.47 $\mathrm{mg} / 100 \mathrm{~g}$ FM in cloudy juices. The pressing also caused a significant decrease in colour parameters. Three months of storage showed markedly decreased contents of carotenoids and vitamin C.
\end{abstract}

Keywords: Cucurbita maxima, Chaenomeles japonica, Fragaria $\times$ ananassa, total polyphenols and carotenoids, vitamin C, turbidity, viscosity

\section{Introduction}

The gradually increasing water and air pollution with organic compounds (Dąbrowska, 2013) and extremely rapid pace of life trigger the development of such civilization diseases as cancer, arterial hypertension and atherosclerosis, and have become a serious concern in society. More and more people are becoming interested in healthy food, and consumers often deliberately choose food products, including vegetables, which are characterized by high nutritive and biological value. Therefore, there is a constant tendency to search for raw materials and processed food products rich in valuable components and featuring good organoleptic (flavour) properties. Pumpkin is one of the fruit vegetables underrated both by the consumer and producer of food products. Pumpkin can be a healthy ingredient of a number of dishes and food products (Nawirska-Olszańska et al., 2011;2012).

The fruit of pumpkin (Cucurbita maxima Duch.) constitutes an easily available, low-calorie raw material for food processing that is rich, first of all, in carotenoids. Moreover, pumpkin contains considerable amounts of vitamins $\mathrm{C}, \mathrm{E}, \mathrm{B}_{6}$, as well as chemical elements such as potassium, phosphorus, magnesium, iron and selenium (Biesiada et al., 2009; Chilczuk et al., 2014; Mazurek and Jamroz, 2010; USDA, 2004). Pumpkin can be used in both salty and sweet food products. Its advantage is a mild flavour, which can be modified, although its slightly cucumber-like scent can bring about some difficulty. In order to solve this issue, pumpkin is mixed with other raw materials having better sensory properties as well as chemical composition.

Strawberry fruits (Fragaria $\times$ ananassa Duch.) have been shown to possess high in vitro antioxidant activity which was positively correlated with polyphenolic content, specifically anthocyanins. The type and quantity of polyphenols are important for analysis of phytochemicals in strawberry (Oszmiański et al., 2011).

Japanese quince fruit (Chaenomeles japonica Thunb.) has high contents of dry matter, fibre and polyphenols, as well as high acidity ( $\mathrm{pH} 2.6$, titrimetric acidity 3.5\% counted over citric acid) and a very pleasant, strong scent (Thomas et al., 2000).

The reason for the use of mash enzymes is the development of mashes with lower viscosities and lower water binding capacities, thus resulting in easier juice extraction and a better working capacity of presses or decanters. In cloudy juice 
184

technology the amount of colloid material in juice was strongly influenced by the method of processing and enzyme preparation used (Oszmiański et al., 2009a). Cloudy juices are complex systems containing fine pulp particles dispersed in a serum constituted by macromolecules (pectins, proteins, etc.) colloidally dissolved in a true solution of low-molecular weight components (organic acids, sugars, etc.) (Oszmiański et al., 2009a; 2011). Light scattering of these particles, which represent cell wall fragments surrounded by negatively charged adsorbed pectin, is perceived as juice turbidity. Cloud stability is one of the visual quality attributes that is decisive for consumer acceptance of cloudy juices (Beveridge, 2002).

The purpose of this research was to compare the physical and chemical properties of puree, puree juice and cloudy juices, where the cloudy juice was prepared using the pectolytic method, on the basis of pumpkin with added Japanese quince fruit and strawberries. The effects of mash maceration on turbidity, cloud stability, total phenolics and carotenoids, vitamin $\mathrm{C}$ and colour properties were studied to evaluate the potential application of enzyme preparations in production of cloudy pumpkin with added fruit juice. This paper shows the possibility of production of puree, puree juices and cloudy pumpkin juices containing Japanese quince and strawberries.

\section{Materials and Methods}

\section{Research materials}

Puree, puree juice and cloudy juices of pumpkin were prepared based on a laboratory scale, on the basis of puree from pumpkin with added purees from Japanese quince and strawberries. The examination was conducted immediately after provision of products, as well as after three-month storage at $4{ }^{\circ} \mathrm{C}$ and $30^{\circ} \mathrm{C}$. Pumpkin of the 'Karowita' cultivar was obtained from the Research and Development Station of Vegetables and Ornamental Plants, Department of Horticulture of the University of Environmental and Life Sciences in Wroctaw. Japanese quince originated from the Botanical Garden in Wrocław, while strawberries of the 'Kent' cultivar were from a retail market. The fresh fruits of pumpkin, Japanese quince and strawberries were ground separately for about $1 \mathrm{~min}$ using a mixer (Thermomix, Wuppertal, Germany).

Preparation of puree, puree juice, and cloudy juices was done on a laboratory scale.

Puree: 10\% Japanese quince and 25\% strawberries were added to the ground pumpkin $(65 \% \mathrm{v} / \mathrm{v})$ (this mixture constituted the base for preparation of the remaining samples) and $20 \%$ water (in relation to fruit puree). Then the mass underwent maceration using the Thermomix mixer for $10 \mathrm{~min}$ at $90^{\circ} \mathrm{C}$.

Puree juice: A $0.02 \%$ pectolytic preparation (Pectinex Smash XXL) and 20\% water (in relation to fruit puree) were added to the base; then it was subjected to maceration using the Thermomix mixer for $3 \mathrm{~h}$ at $45^{\circ} \mathrm{C}$.

Cloudy juice 1: The base was pressed without maceration and without pectolytic preparation.

Cloudy juice 2: A $0.05 \%$ pectolytic preparation (Pectinex Smash XXL) and 20\% water (in relation to fruit puree) were added to the base, and then the fruit mass was subjected to maceration using the Thermomix mixture for $3 \mathrm{~h}$ at $45^{\circ} \mathrm{C}$, and finally pressed.

Cloudy juice 3: The base was supplemented with a $0.05 \%$ pectolytic preparation and $0.05 \%$ amyloglucosidase preparation (AMYLASE AG XXI) and 20\% water (in relation to fruit puree), then macerated using the Thermomix mixture for $1.5 \mathrm{~h}$ at $50^{\circ} \mathrm{C}$, then pressed.

All samples were placed in jars of $120 \mathrm{ml}$ capacity and pasteurized for $30 \mathrm{~min}$ at $85^{\circ} \mathrm{C}$.

\section{Analyticalmethods}

Chemical characteristics of pumpkin samples involved determination of extract content according to the PN-90/A75101/02 standard, dry matter (AOAC 920.151), ash (AOAC 930.09), vitamin C as L-ascorbic acid (PN-A-04019 standard), total carotenoids (PN-90/A 75101/12 standard) and total polyphenols content by the Folin-Ciocalteu method (Olssen $e t$ al., 2006). Determination of total polyphenols content was performed in methanol extracts $(80 \% \mathrm{v} / \mathrm{v}$, material to extracting agent ratio was 1:5) and expressed as the gallic acid equivalent.

\section{Instrumental analysis of colour}

The colour of the pumpkin puree samples (reflectance values: $L^{*}, a^{*}$ and $b^{*}$ ) was measured using a Color Quest XE (HunterLab) (USA) spectrophotometer. Each puree was placed in a glass cuvette, and the colour $L^{*}, a^{*}, b^{*}$ values were determined using Illuminant D65 and an observer angle of $10^{\circ}$. $\mathrm{L}^{*}$ denotes 'lightness', and its values range from 0 to 100 ( 0 for ideal black, and 100 for ideal white). A positive value of $a^{*}$ indicates 'red colour', a negative value of $a^{*}$ indicates 'green colour', a positive value of $b^{*}$ indicates 'yellow colour', and a negative value of $b^{*}$ indicates 'blue colour'.

\section{Turbidity measurement}

Turbidity of juices was measured with a Turbiquant 3000T turbidimeter (Merck, Germany) using $2.5 \mathrm{~cm}$ round cuvettes. The turbidity was expressed in nephelometric turbidity units (NTU). The resistance to clarification (cloud stability) was deduced from the percentage relative turbidity (T\%):

$\mathrm{T} \%=(\mathrm{Tc} / \mathrm{To}) \times 100$

where To and $\mathrm{Tc}_{\mathrm{c}}$ are the juice turbidities before and after centrifugation at $4200 \mathrm{~g}$ for $15 \mathrm{~min}$ at $20{ }^{\circ} \mathrm{C}$, respectively (Oszmiański 2009a).

Viscosity measurement

The viscosities of the cloudy apple juices were measured with a rotation viscometer MC1 (DV-II+PRO VISCOMETER, Brookfield, England). All measurements were carried out at 20 ${ }^{\circ} \mathrm{C}$. The results were expressed in mPa॰s.

\section{Statistical analysis}

The data obtained were analyzed statistically. The results were presented as the mean and standard deviation (SD) of three independent determinations. All data were recorded as mean values \pm SD. Analysis of variance was performed by applying the ANOVA procedure, and statistical analysis was conducted using Statistica 8.1 software (StatSoft Poland). Significant differences $(\mathrm{p}<0.05)$ between the mean values were determined by Duncan's multiple range test.

\section{Results and Discussion}

Physical and chemical properties, including viscosity of pumpkin puree, puree juice and cloudy juices enriched with Japanese quince and strawberries, before and after three-month 
Table 1. Dry matter and ash contents of pumpkin preserved with addition of Japanese quince and strawberry before and after three months of storage at $4{ }^{\circ} \mathrm{C}$ and $30^{\circ} \mathrm{C}$

\begin{tabular}{lcccccc}
\hline \multirow{2}{*}{ Sample } & \multicolumn{3}{c}{ Dry matter [\%] } & \multicolumn{3}{c}{ Ash [\%] } \\
\cline { 2 - 7 } & 0 & $3 \mathrm{~F}$ & $3 \mathrm{H}$ & 0 & $3 \mathrm{~F}$ & $3 \mathrm{H}$ \\
\hline Puree & $8.61 \pm 0.14 \mathrm{aA}$ & $8.07 \pm 0.13 \mathrm{aC}$ & $8.15 \pm 0.14 \mathrm{aB}$ & $0.79 \pm 0.04 \mathrm{aA}$ & $0.67 \pm 0.04 \mathrm{aB}$ & $0.57 \pm 0.09 \mathrm{cC}$ \\
Puree juice & $6.70 \pm 0.17 \mathrm{bA}$ & $6.58 \pm 0.10 \mathrm{bB}$ & $6.29 \pm 0.15 \mathrm{bC}$ & $0.49 \pm 0.07 \mathrm{cA}$ & $0.47 \pm 0.07 \mathrm{cB}$ & $0.43 \pm 0.02 \mathrm{dC}$ \\
Cloudy juice 1 & $6.10 \pm 0.11 \mathrm{cA}$ & $6.04 \pm 0.12 \mathrm{eB}$ & $5.87 \pm 0.14 \mathrm{cC}$ & $0.69 \pm 0.09 \mathrm{bA}$ & $0.58 \pm 0.02 \mathrm{abB}$ & $0.57 \pm 0.05 \mathrm{cB}$ \\
Cloudy juice 2 & $6.39 \pm 0.11 \mathrm{bA}$ & $6.36 \pm 0.14 \mathrm{cB}$ & $6.03 \pm 0.08 \mathrm{cC}$ & $0.78 \pm 0.04 \mathrm{aA}$ & $0.64 \pm 0.05 \mathrm{aB}$ & $0.61 \pm 0.03 \mathrm{bB}$ \\
Cloudy juice 3 & $6.39 \pm 0.08 \mathrm{bA}$ & $6.16 \pm 0.11 \mathrm{dC}$ & $6.23 \pm 0.14 \mathrm{bB}$ & $0.77 \pm 0.08 \mathrm{aA}$ & $0.66 \pm 0.04 \mathrm{abB}$ & $0.59 \pm 0.09 \mathrm{aC}$ \\
\hline
\end{tabular}

Explanatory notes: 0 - before storage; $3 \mathrm{~F}$ - after 3 months of storage at $4{ }^{\circ} \mathrm{C}$; $3 \mathrm{H}$ - after 3 months of storage at $30^{\circ} \mathrm{C}$; different letters $(\mathrm{a}, \mathrm{b}, \mathrm{c}$ ) within the same column indicate statistically significant differences $(\mathrm{p}<0.05)$; different letters $(\mathrm{A}, \mathrm{B}, \mathrm{C})$ within the same row indicate statistically significant differences $(\mathrm{p}<0.05)$.

Table 2. Total soluble solids and viscosity of pumpkin preserved with addition of Japanese quince and strawberry before and after three months of storage at $4{ }^{\circ} \mathrm{C}$ and $30^{\circ} \mathrm{C}$

\begin{tabular}{lcccccc}
\hline \multirow{2}{*}{ Sample } & \multicolumn{3}{c}{ Total soluble solids [ ${ }^{\circ}$ Brix] } & \multicolumn{3}{c}{ Viscosity [mPa s $]$} \\
\cline { 2 - 7 } & 0 & $3 \mathrm{~F}$ & $3 \mathrm{H}$ & 0 & $3 \mathrm{~F}$ & $3 \mathrm{H}$ \\
\hline Puree & $6.5 \pm 0.11 \mathrm{aA}$ & $6.2 \pm 007 \mathrm{bB}$ & $6.5 \pm 0.12 \mathrm{aA}$ & $1158.0 \pm 78.14 \mathrm{aC}$ & $1293.0 \pm 56.10 \mathrm{aB}$ & $1761.8 \pm 299 \mathrm{aA}$ \\
Puree juice & $5.0 \pm 0.14 \mathrm{cA}$ & $4.9 \pm 0.14 \mathrm{cB}$ & $5.0 \pm 0.09 \mathrm{cA}$ & $296.9 \pm 5.19 \mathrm{bB}$ & $356.9 \pm 4.78 \mathrm{bA}$ & $299.9 \pm 8.98 \mathrm{bB}$ \\
Cloudy juice 1 & $6.3 \pm 0.12 \mathrm{bA}$ & $6.1 \pm 0.17 \mathrm{bB}$ & $6.1 \pm 0.11 \mathrm{bB}$ & $2.30 \pm 0.14 \mathrm{cA}$ & $2.22 \pm 0.23 \mathrm{cA}$ & $2.21 \pm 0.14 \mathrm{cA}$ \\
Cloudy juice 2 & $6.6 \pm 0.16 \mathrm{Aa}$ & $6.5 \pm 0.14 \mathrm{Ab}$ & $6.4 \pm 0.13 \mathrm{Ac}$ & $1.50 \pm 0.17 \mathrm{cA}$ & $1.38 \pm 0.25 \mathrm{cA}$ & $1.35 \pm 0.16 \mathrm{cA}$ \\
Cloudy juice 3 & $6.6 \pm 0.14 \mathrm{aA}$ & $6.4 \pm 0.09 \mathrm{aB}$ & $6.4 \pm 0.14 \mathrm{aB}$ & $1.49 \pm 0.19 \mathrm{cA}$ & $1.43 \pm 0.14 \mathrm{cA}$ & $1.41 \pm 0.19 \mathrm{cA}$ \\
\hline
\end{tabular}

Explanatory notes: 0 - before storage; $3 \mathrm{~F}$ - after 3 months of storage at $4{ }^{\circ} \mathrm{C} ; 3 \mathrm{H}$ - after 3 months of storage at $30{ }^{\circ} \mathrm{C}$; different letters $(\mathrm{a}$, b, c) within the same column indicate statistically significant differences $(\mathrm{p}<0.05)$; different letters $(\mathrm{A}, \mathrm{B}, \mathrm{C})$ within the same row indicate statistically significant differences $(\mathrm{p}<0.05)$.

storage at $4{ }^{\circ} \mathrm{C}$ and $30^{\circ} \mathrm{C}$, are shown in Tables 1 and 2 . Based on the literature, there are no reports on puree, puree juice and cloudy juices obtained from pumpkin.

Dry matter content of the analyzed purees ranged from 6.10 to $8.61 \%$, and it diminished after storage (Table 1). The decrease in the value of that parameter was dependent on the type of samples. In puree juice, as well as in cloudy juices 1 and 2 , significant decreases in dry matter were observed after storage at $30^{\circ} \mathrm{C}$, and also in puree and in cloudy juice 3 after cold storage.

In all the samples after storage for three months, a decrease in ash content was observed. The initial ash content ranged from $0.49 \%$ to $0.79 \%$. After cold storage, the content decreased to $0.47-0.66 \%$, and at $30{ }^{\circ} \mathrm{C}$ the ash content decreased to $0.43-0.61 \%$. The highest loss in ash content was observed in the puree stored at $30^{\circ} \mathrm{C}$ (from 0.79 to $0.57 \%$ ). Statistical analysis showed that, in most cases, storage condition had a significant effect on ash content.

The content of extract in the majority of examined nonstored products was at a similar level of 6.3-6.6\%. Only in puree juice did it significantly differ from that value, being $5.0 \%$. After storage for three months, the amount of total soluble solids obtained was decreased or unchanged in all samples, except puree and puree juice stored at $30^{\circ} \mathrm{C}$, where the mentioned parameter remained at the same level (Table 2).

The high viscosity values in the pumpkin samples featured puree and puree juice (Table 2). Increased values of viscosity were observed after storage for three months in both of the samples, and the highest increase in viscosity was determined for the puree stored at $30^{\circ} \mathrm{C}$. In puree juice, after storage at $30{ }^{\circ} \mathrm{C}$, the increase in that parameter was not statistically significant $(p<0.05)$. Viscosity of cloudy juices, regardless of the technology of their production, proved to be quite low and after storage its values slightly decreased, although the differences were not statistically significant $(p<0.05)$. It is known that the reason for the use of mash enzymes is development of mash with lower viscosity, thus resulting in easier juice extraction and better working capacity of presses or decanters. These effects are positive in production of clear apple juices but in cloudy juices the use of enzymatic mash maceration caused instability of turbidity and sediment decantation (Oszmiański et al., 2009a). Nawirska-Olszańska et al. (2011), in their research on pumpkin puree enriched with, among other things, strawberries and Japanese quince, reported considerably lower viscosity values, which could result from a different technology used during puree storage research. Investigating the effect of different enzymatic preparations on the quality of apple juices, Oszmiański et al. (2009) observed a decrease in viscosity values under the influence of enzymatic preparations and an increase in viscosity values after 6-month storage. Addition of ascorbic acid to the apple pulp has a significant impact on the level of viscosity of apple juices (Kolniak-Ostek et al., 2013). Also, Kucharska et al. (2010) observed increased viscosity after storage of dogwood fruit puree with additives.

Pumpkin products made of raw material rich in carotenoids (2-10 mg $100 \mathrm{~g}^{-1} \mathrm{FM}$ ) contained considerable amounts of that component (Niewczas and Mitek 2007). The carotenoids content of pumpkin samples are shown in Table 3. In a study by Biesiada et al. (2009), pumpkin of the 'Karowita' cultivar contained $8.52 \mathrm{mg} 100 \mathrm{~g} \mathrm{~g}^{-1}$ FM. The addition of Japanese quince and strawberries, as well as pectolytic enzymes, caused a significant decrease in carotenoids content. The pressing process had the greatest effect on carotenoids content in the samples, causing a decrease in carotenoids content

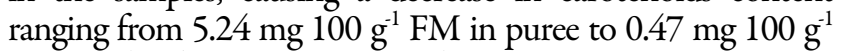
FM in cloudy juice pressed without enzymatic preparations. Addition of enzymatic preparations also reduced the carotenoids content in the final product. There were also no statistical differences for carotenoids content between the preparations applied (cloudy juices 2 and 3). Storage conditions did significantly $(\mathrm{p}<0.05)$ reduce carotenoids content in the examined samples. A greater decrease in carotenoids content was observed in samples stored at $30^{\circ} \mathrm{C}$. Only in the case of puree juice did the storage conditions not 
186

Table 3. Content of selected bioactive components in pumpkin preserved with Japanese quince and strawberry before and after three months of storage at $4{ }^{\circ} \mathrm{C}$ and $30^{\circ} \mathrm{C}$

\begin{tabular}{|c|c|c|c|c|c|c|c|c|c|}
\hline \multirow{2}{*}{ Sample } & \multicolumn{3}{|c|}{ Carotenoids $\left[\mathrm{mg} 100 \mathrm{~g}^{-1} \mathrm{FM}\right]$} & \multicolumn{3}{|c|}{ Total polyphenol $s\left[\mathrm{mgGAE} 100 \mathrm{~g}^{-1} \mathrm{FM}\right]$} & \multicolumn{3}{|c|}{ Vitamin $\mathrm{C}\left[\mathrm{mg} 100 \mathrm{~g}^{-1} \mathrm{FM}\right]$} \\
\hline & 0 & $3 \mathrm{~F}$ & $3 \mathrm{H}$ & 0 & $3 \mathrm{~F}$ & $3 \mathrm{H}$ & 0 & $3 \mathrm{~F}$ & $3 \mathrm{H}$ \\
\hline Puree & $5.24 \pm 0.11 \mathrm{aA}$ & $4.71 \pm 0.08 \mathrm{aB}$ & $4.06 \pm 0.06 \mathrm{aC}$ & $89.98 \pm 9.01 \mathrm{aB}$ & $302.44 \pm 23.11 \mathrm{aA}$ & $366.08 \pm 14.19 \mathrm{aA}$ & $5.17 \pm 0.08 \mathrm{aA}$ & $4.09 \pm 0.15 \mathrm{aB}$ & $1.42 \pm 0.05 \mathrm{bC}$ \\
\hline Puree juice & $4.15 \pm 0.17 \mathrm{aA}$ & $4.04 \pm 0.15 \mathrm{aB}$ & $4.05 \pm 0.11 \mathrm{aB}$ & $69.96 \pm 5.18 \mathrm{bB}$ & $262.01 \pm 31.11 \mathrm{aA}$ & $271.48 \pm 17.45 \mathrm{aA}$ & $3.24 \pm 0.05 \mathrm{cA}$ & $1.48 \pm 0.09 \mathrm{eB}$ & $1.34 \pm 0.05 \mathrm{cB}$ \\
\hline Cloudy juice 1 & $0.47 \pm 0.19 \mathrm{bA}$ & $0.36 \pm 0.11 \mathrm{bB}$ & $0.27 \pm 0.14 \mathrm{bC}$ & $44.72 \pm 4.11 \mathrm{cA}$ & $38.11 \pm 4.19 \mathrm{cB}$ & $39.44 \pm 4.15 \mathrm{cB}$ & $3.10 \pm 0.13 \mathrm{dA}$ & $2.57 \pm 0.05 \mathrm{bB}$ & $2.20 \pm 0.09 \mathrm{aC}$ \\
\hline Cloudy juice 2 & $0.19 \pm 0.01 \mathrm{cA}$ & $0.14 \pm 0.09 \mathrm{cB}$ & $0.10 \pm 0.03 \mathrm{cC}$ & $62.15 \pm 3.19 \mathrm{bA}$ & $44.75 \pm 9.14 \mathrm{cB}$ & $61.43 \pm 33.16 \mathrm{cA}$ & $3.29 \pm 0.07 \mathrm{cA}$ & $2.37 \pm 0.12 \mathrm{~dB}$ & $1.15 \pm 0.06 \mathrm{eC}$ \\
\hline Cloudy juice 3 & $0.18 \pm 0.09 \mathrm{cA}$ & $0.12 \pm 0.00 \mathrm{cB}$ & $0.06 \pm 0.01 \mathrm{cC}$ & $46.20 \pm 5.11 \mathrm{cB}$ & $43.97 \pm 7.17 \mathrm{cB}$ & $56.98 \pm 15.19 \mathrm{cA}$ & $3.76 \pm 0.18 \mathrm{bA}$ & $2.48 \pm 0.05 \mathrm{cB}$ & $1.22 \pm 0.08 \mathrm{dC}$ \\
\hline
\end{tabular}

Table 4. Colour parameters $L^{*}, a^{*}, b^{*}$ of pumpkin preserved with addition of Japanese quince and strawberry before and after three months of storage at $4{ }^{\circ} \mathrm{C}$ and $30^{\circ} \mathrm{C}$

\begin{tabular}{lccccccccc}
\hline \multirow{2}{*}{ Preserve } & \multicolumn{3}{c}{$L^{*}$} & \multicolumn{3}{c}{$a^{*}$} & \multicolumn{3}{c}{$b^{*}$} \\
\cline { 2 - 10 } & 0 & $3 \mathrm{~F}$ & $3 \mathrm{H}$ & 0 & $3 \mathrm{~F}$ & $3 \mathrm{H}$ & 0 & $3 \mathrm{~F}$ & $3 \mathrm{H}$ \\
\hline Puree & $44.49 \pm 0.04 \mathrm{aC}$ & $47.28 \pm 0.30 \mathrm{aA}$ & $45.03 \pm 0.03 \mathrm{aB}$ & $18.78 \pm 0.2 \mathrm{laA}$ & $17.08 \pm 0.06 \mathrm{aB}$ & $14.41 \pm 0.81 \mathrm{aC}$ & $26.76 \pm 0.09 \mathrm{aC}$ & $29.81 \pm 0.21 \mathrm{aA}$ & $27.01 \pm 0.43 \mathrm{aB}$ \\
Puree juice & $43.93 \pm 0.03 \mathrm{aB}$ & $44.69 \pm 0.13 \mathrm{bA}$ & $44.97 \pm 0.11 \mathrm{aA}$ & $16.68 \pm 0.06 \mathrm{aA}$ & $14.74 \pm 0.01 \mathrm{aB}$ & $12.78 \pm 0.57 \mathrm{aC}$ & $26.24 \pm 0.11 \mathrm{aA}$ & $26.55 \pm 0.21 \mathrm{aA}$ & $25.47 \pm 0.41 \mathrm{aB}$ \\
Cloudyjuice 1 & $30.90 \pm 0.06 \mathrm{bB}$ & $31.41 \pm 0.11 \mathrm{cA}$ & $31.59 \pm 0.04 \mathrm{bA}$ & $5.17 \pm 0.02 \mathrm{bA}$ & $3.27 \pm 0.61 \mathrm{bB}$ & $2.57 \pm 0.72 \mathrm{bC}$ & $5.21 \pm 0.01 \mathrm{bA}$ & $4.47 \pm 0.57 \mathrm{bB}$ & $3.56 \pm 0.08 \mathrm{bC}$ \\
Cloudyjuice 2 & $27.58 \pm 0.20 \mathrm{cB}$ & $28.44 \pm 0.21 \mathrm{dA}$ & $28.37 \pm 0.23 \mathrm{cA}$ & $3.14 \pm 0.06 \mathrm{bA}$ & $2.41 \pm 0.01 \mathrm{bB}$ & $1.63 \pm 0.05 \mathrm{bC}$ & $1.13 \pm 0.14 \mathrm{bB}$ & $0.90 \pm 0.06 \mathrm{cC}$ & $1.28 \pm 0.09 \mathrm{bA}$ \\
Cloudy juice 3 & $28.43 \pm 0.14 \mathrm{cB}$ & $29.02 \pm 0.01 \mathrm{dA}$ & $29.17 \pm 0.15 \mathrm{cA}$ & $3.69 \pm 0.04 \mathrm{bA}$ & $2.48 \pm 0.01 \mathrm{bB}$ & $1.71 \pm 0.01 \mathrm{bC}$ & $1.14 \pm 0.03 \mathrm{bB}$ & $1.14 \pm 0.01 \mathrm{cB}$ & $1.50 \pm 0.14 \mathrm{bA}$ \\
\hline
\end{tabular}

Explanatory notes: 0 - before storage; $3 \mathrm{~F}$ - after 3 months of storage at $4{ }^{\circ} \mathrm{C} ; 3 \mathrm{H}$ - after 3 months of storage at $30^{\circ} \mathrm{C}$; different letters $(\mathrm{a}$, b, c) within the same column indicate statistically significant differences $(\mathrm{p}<0.05)$; different letters $(\mathrm{A}, \mathrm{B}, \mathrm{C})$ within the same row indicate statistically significant differences $(\mathrm{p}<0.05)$.

influence the carotenoids content. The results obtained in this study confirm the previous findings by Nawirska-Olszańska et al. (2011), who examined the effect of adding Japanese quince and strawberry to pumpkin puree on the decrease in carotenoids content.

Technology of juice production significantly affects the content of phenolic compounds, which was proved in the research by Cliff et al. (1991). Considerable differences in polyphenols content in the final products of pumpkin may also be due to the conditions of conducting technological processes. The losses in polyphenols caused by pressing the raw material can amount even up to $50 \%$ (Oszmiański et al., 2009a). Therefore, in the research by these authors, the highest quantity of the polyphenols was found in the least processed sample, i.e. in pumpkin puree. A significant increase in total polyphenols content was observed for puree and puree juice $(p<0.05)$. After storage of puree juice at of $30^{\circ} \mathrm{C}$, there was a slight increase in polyphenols content, while the cold storage polyphenols showed decreased total polyphenols content. In the remaining samples, regardless of the storage conditions, a decrease in total polyphenols content was observed. Therefore, it can be concluded that changes in total polyphenols content were more influenced by the types of samples than by the conditions of their storage.

Vitamin $C$ in the pumpkin samples ranged from 1.15 to 5.17 mg $100 \mathrm{~g}^{-1} \mathrm{FM}$, as shown in Table 3. The addition of enzymatic preparations caused its significant reduction. Storage conditions considerably affected the vitamin $\mathrm{C}$ level in the samples studied, and also resulted in a decrease of vitamin $C$ level. The loss in vitamin $\mathrm{C}$ was significantly lower when the samples were stored at $4{ }^{\circ} \mathrm{C}$ than at $30^{\circ} \mathrm{C}$. The only exception was puree juice, where storage conditions were not significantly effective $(p<0.05)$. The fall in vitamin $\mathrm{C}$ content, when storage took place at $30^{\circ} \mathrm{C}$, was $72 \%$ in puree, and at $4{ }^{\circ} \mathrm{C}$, the decrease in vitamin $\mathrm{C}$ content was $54 \%$ in puree juice. These results are consistent with those obtained by Mazurek and Jamroz (2010), who reported a much greater decrease in vitamin $\mathrm{C}$ content in juices stored at $21{ }^{\circ} \mathrm{C}$ compared with $4^{\circ} \mathrm{C}$.
Puree and puree juice showed a significantly higher value of the $L^{*}$ parameter $(\mathrm{p}<0.05)$ responsible for colour lightness, parameter $a^{*}$ determining the colour dimension from red to green, and parameter $b^{*}$ determining the colour dimension from yellow to blue in perceived colour (Table 4).

The storage conditions generally did not significantly influence the colour brightness of pumpkin samples, except puree. Enzymatic preparations also did not significantly affect the alteration in lightness and colour of the samples. The process of pressing had a considerable impact on the change in colour. This is also consistent with the conclusion reached by Mihalev et al. (2004) that colour changed with oxidation, not with enzymatic treatment and storage time.

The highest proportion of red colour characterised the pumpkin samples while in preparation. Storage also resulted in a significant decrease in that colour, which was greater in the case of storage at $30^{\circ} \mathrm{C}$. This is probably related to degradation of anthocyanins present in strawberries.

The changes in parameter $b^{*}$ did not show similar tendencies, but they were related to the type of sample. The process of storage diversely influenced the value of that parameter. The alterations in colour parameters $a^{*}$ and $b^{*}$ indicated the presence of negative processes in the samples, connected with turning brown during storage, especially when stored at $30^{\circ} \mathrm{C}$. Similar changes were observed by Kucharska $e t$ al. (2010) in their research on the effect of storage on dogwood fruit puree with additives. Additionally, for cloudy juices, we calculated the stability of their turbidity, and the results are shown in Table 5.

In the course of storage, the turbidity of cloudy juice 2 and cloudy juice 3 increased. However, for cloudy juice 1, the values of that parameter decreased. It can be concluded from statistical calculations that the storage conditions significantly influenced turbidity of the majority of examined juices. The addition of enzymatic preparations significantly affected the examined property as well. The smallest alteration in turbidity after storage was shown by cloudy juice 3 stored in the refrigerator. This 
Table 5. Turbidity and stability of turbidity of pumpkin cloudy juices with addition of Japanese quince and strawberry before and after three months of storage at $4{ }^{\circ} \mathrm{C}$ and $30^{\circ} \mathrm{C}$

\begin{tabular}{lcccccc}
\hline \multirow{2}{*}{ Preserve } & \multicolumn{3}{c}{ Turbidity [NUT] } & \multicolumn{3}{c}{ Stability of turbidity [\%] } \\
\cline { 2 - 7 } & 0 & $3 \mathrm{~F}$ & $3 \mathrm{H}$ & 0 & $3 \mathrm{~F}$ & $3 \mathrm{H}$ \\
\hline Cloudy juice 1 & $1171 \pm 69 \mathrm{aA}$ & $790 \pm 34 \mathrm{cC}$ & $960 \pm 93 \mathrm{aB}$ & $9 \pm 0.9 \mathrm{bA}$ & $8 \pm 0.9 \mathrm{bB}$ & $7 \pm 0.6 \mathrm{aC}$ \\
Cloudy juice 2 & $194 \pm 13 \mathrm{cC}$ & $273 \pm 63 \mathrm{bB}$ & $467 \pm 25 \mathrm{bA}$ & $25 \pm 2.1 \mathrm{aA}$ & $12 \pm 1.3 \mathrm{aB}$ & $8 \pm 0.8 \mathrm{aC}$ \\
Cloudy juice 3 & $304 \pm 42 \mathrm{bB}$ & $334 \pm 33 \mathrm{aB}$ & $510 \pm 32 \mathrm{bA}$ & $9 \pm 0.9 \mathrm{bA}$ & $3 \pm 0.4 \mathrm{cB}$ & $1 \pm 0.3 \mathrm{bC}$ \\
\hline
\end{tabular}

Explanatory notes: 0 - before storage; $3 \mathrm{~F}$ - after 3 months of storage at $4{ }^{\circ} \mathrm{C} ; 3 \mathrm{H}$ - after 3 months of storage at $30^{\circ} \mathrm{C}$; different letters $(\mathrm{a}, \mathrm{b}, \mathrm{c})$ within the same column indicate statistically significant differences $(\mathrm{p}<0.05)$; different letters $(A, B, C)$ within the same row indicate statistically significant differences $(\mathrm{p}<0.05)$, NTU: nephelometric turbidity unit.

observation is consistent with a study conducted by Oszmiański et al. (2009) on turbidity of apple juices enriched with different enzymatic preparations.

The calculated stability of turbidity of juices after storage decreased, yet that decrease was different for particular juices. It was found that storage conditions significantly affected the decreases in values of that parameter. The lowest stabilization was recorded for juices after storage under the conditions of elevated temperature. According to research results by Oszmiański et al. (2009), turbidity of apple juices supplemented with enzymatic preparations increased after six months of storage. Additionally, stability of turbidity in apple juices was higher than in pumpkin juices enriched with Japanese quince fruit and strawberries. That discrepancy could have resulted from the properties of the raw material used for the production of cloudy juices.

The degree of turbidity and stability of turbidity are the important parameters that reflect the quality of cloudy juices. Dietrich et al. (1996) claim that the quality of turbidity for cloudy apple juices should exceed $50 \%$ and 250 NTU.

\section{Conclusions}

The conditions of cold storage significantly affected the decrease in ash content, vitamin C, and total polyphenols, as well as causing lesser preservation of colour (parameter $a^{*}$ ) in the obtained puree from pumpkin fruit enriched with Japanese quince fruit and strawberries. Puree and puree juice from pumpkin, containing additives, can be classified as products rich in carotenoids. The pressing process had a significant impact on the decrease during storage in their content in the obtained samples. Pressing and storage conditions considerably affected the total polyphenols content in the examined samples. Stability of turbidity of the juices subjected to investigation was low, from 9 to $25 \%$ in non-stored juices, while in the stored ones it ranged from 1 to $8 \%$ at $30^{\circ} \mathrm{C}$ and from 3 to $12 \%$ at $4{ }^{\circ} \mathrm{C}$.

The results of the present study demonstrate that pumpkin with Japanese quince and strawberries is a very good compilation of production puree, puree juice and cloudy juices. Added to pumpkin, Japanese quince and strawberries had a positive effect by improving total polyphenolics, carotenoids and vitamin C contents. However, in the case of enzymatic mash treatment, cloudy juices showed instability of turbidity and low viscosity.

\section{References}

AOAC (2005). Official methods of analysis of AOAC International. In: Horowitz W, Latimer GE (18th Edn). AOAC International, Maryland.
Biesiada A, Nawirska A, Kucharska AZ, Sokót-Łętowska A (2009). The effect of nitrogen fertilization methods on yield and chemical composition of pumpkin (Cucurbita maxima) fruits before and after storage. Vegetable Crops Research Bulletin 70:202-211.

Beveridge T (2002). Opalescent and cloudy fruit juices: formation and particle stability Critical Reviewsin Food Science Nutrition 42:317-337.

Chilczuk B, Perucka I, Materska M, Buczkowska H (2014). Zawartość luteiny, zeaksantyny i $\beta$-karotenu w liofilizowanych owocach wybranych odmian Cucurbita maxima D. [Content of lutein, zeaxanthin, and $\beta$ carotene in lyophilized fruits of selected cultivars of Cucurbita maxima D.].Żywność Nauka TechnologiaJakość2(93):139-150 (in Polish with English abstract).

Cliff M, Dever MC, Gayton R (1991). Juice extraction process and apple cultivar influence on juice properties. Journal of Food Science 56(6):16141617.

Dąbrowska A (2013). Przyczyny występowania zwiększonych ilości aldehydów w wodach powierzchniowych [Possible reasons for elevated aldehyde levels in surface waters]. Ochrona Środowiska 35(3):13-16 (in Polish with English abstract).

Dietrich H, Gierschner K, Pecoroni S, Zimmer E, Will F (1996). Neue erkenntnisse zu dem phanomen der trubungsstabilitats erste ergebnisse aus einem laufenden forschungsprogramm, [New insights into the phenomenon of stability of turbidity first results from an ongoing research program]. Flüss Obst 63:7-10.

Kolniak-Ostek J, Oszmiański J, Wojdyło A (2013). Effect of l-ascorbic acid addition on quality, polyphenolic compounds and antioxidant capacity of cloudy apple juices. European Food Research and Technology 236:777-798.

Kucharska AZ, Kowalczyk K, Nawirska-Olszańska A, SokółŁętowska A (2010). Wplyw dodatku aronii, truskawek i malin na skład fizykochemiczny przecieru dereniowego [Effect of chokeberry, strawberry, and raspberry added to cornelian cherry purée on its physical and chemical composition]. Żywność Nauka Technologia Jakość 4(71):95-106 (in Polish with English abstract).

Mazurek A,JamrozJ (2010).Stabilność witaminy C w sokach owocowych i nektarach z czarnej porzeczki podczas przechowywania [Vitamin C stability in fruit juices and black currant nectar during storage]. Acta Agrophysica 16(1):93-100 (in Polish with English abstract).

Mihalev K, Schieber A, Mollov P, Carle R (2004). Effect of mash maceration on the polyphenolic content and visual quality attributes of cloudy apple juice.Journal of Agricultural and Food Chemistry 52:7306-7310.

Nawirska-Olszańska A, Biesiada A, Sokół-Łętowska A, Kucharska AZ (2011). Content of bioactive compounds and antioxidant capacity of pumpkin puree enriched with Japanese quince, cornelian cherry, 
188

strawberry and apples. Acta Scientarum Polonarum Technologia Alimentaria 10(1):51-60.

Nawirska-Olszańska A, Biesiada A, Kucharska AZ, Sokół-Łętowska A (2012). Wpływ sposobu przygotowania i warunków przechowywania przecierów, soków przecierowych i soków mętnych z owoców dyni olbrzymiej z dodatkiem owoców pigwowca i derenia na ich właściwości fizykochemiczne [Effect of production method and storage conditions of pumpkin preserves enriched with Japanese quince and cornelian cherry on their physical-chemical properties]. Żywność Nauka Technologia Jakość3(82):168-178 (in Polish with English abstract).

Niewczas J, Mitek M (2007). Wplyw przechowywania nowych odmian dyni olbrzymiej (Cucurbita maxima) na wybrane parametry składu chemicznego [The storage influence on selected chemical composition parameters of new varieties of the winter squash (Cucurbita Maxima)]. Żywność Nauka Technologia Jakość 5(54):155-164 (in Polish with English abstract).

Olssen ME, Andersson S, Oredsson S, Berglund RH, Gustavsson KR (2006). Antioxidant levels and inhibition of cancer cell proliferation in vitro by extracts from organically and conventionally cultivated strawberries. Journal of Agricultural and Food Chemistry 54:12481255.
Oszmiański J, Wojdyło A, Kolniak J (2009). Effect of L-ascorbic acid, sugar, pectin and freeze-thaw treatment on polyphenol content of frozen strawberries. LWT-Food Science and Technology 42:581-586.

Oszmiański J, Wojdyło A, Kolniak J (2009a). Effect of enzymatic mash treatment and storage on phenolic composition, antioxidant activity, and turbidity of cloudy apple juice. Journal of Agricultural and Food Chemistry 57:7078-7085.

OszmiańskiJ, Wojdyło A, KolniakJ (2011).Effect of pectinase treatment on extraction of antioxidant phenols from pomace, for the production of puree-enriched cloudy apple juices. Food Chemistry 127:623-631.

PN-90/A-75101/02 (1990). Food products determination of extract.

PN-A-04019 (1998). Food products determination of ascorbic acid.

PN-90-75101/12 (1990) Food products determination of carotenoids.

Thomas M, Crépeau MJ, Rumpunen K, Thibault J.-F (2000). Dietary fibre and cell-wall polysaccharides in the fruits of Japanese quince (Chaenomeles japonica). LWT - Food Science and Technology 33:24 131.

USDA National Nutrient Database for Standard Reference (2004). Nutritional value of pumpkin and winter squash. Release 17. 